\title{
Daya Hasil Galur-Galur Kacang Tanah (Arachis hypogaea L.) Tahan Penyakit Bercak Daun di Kecamatan Ciranjang Kabupaten Cianjur Provinsi Jawa Barat
}

\section{Yield of Peanut (Arachis hypogaea L.) Leaf Spot Resistant Lines in Ciranjang District, Cianjur Regency, West Java Province}

\author{
Yudiwanti Wahyu*, Dede Rosyana Budiman \\ Departemen Agronomi dan Hortikultura, Fakultas Pertanian, Institut Pertanian Bogor \\ (Bogor Agricultural University), Jl. Meranti, Kampus IPB Darmaga, Bogor 16680, Indonesia \\ Telp.\&Faks.62-251-8629353 e-mail agronipb@indo.net.id
}

\begin{abstract}
This research was aimed to evaluate the yield of 16 peanut leafspot resistant lines derived from cross between Gajah variety and GPNC-WS 4 line with four check varieties of peanut. The four check varieties of peanut consist of Gajah, Jerapah, Zebra Putih, and Sima. The experiment was carried out at Ciranjang District, Cianjur Regency, West Java, from February to May 2011. This research was arranged in randomized complete block design with three replications. Result showed that GWS 39 D, GWS 110 D, GWS 18 A1, GWS 79 A, and GWS 110 A2 were identified as lines with high yield. GWS 74 D, GWS 39 B, GWS 79 A, GWS 73 D, GWS 18 A1, GWS 134 Al, and GWS 110 Al were identified as lines with high resistant level to leafspot of peanut. Two of sixteen lines had high yield and high resistant level to leafspot, they were GWS 79 A and GWS $18 \mathrm{Al}$.
\end{abstract}

Key words : peanut, yield evaluation, leaf spot resistant

\section{ABSTRAK}

Penelitian ini bertujuan untuk mengevaluasi hasil dari 16 galur kacang tanah tahan penyakit bercak daun yang berasal dari persilangan antara varietas Gajah dan galur GPNC-WS 4 dengan empat varietas pembanding yaitu Gajah, Jerapah, Zebra Putih, dan Sima. Penelitian dilakukan di Kecamatan Ciranjang, Kabupaten Cianjur, Jawa Barat, dari bulan Februari sampai Mei 2011. Penelitian ini disusun dalam rancangan kelompok lengkap teracak (RKLT) dengan tiga ulangan. Hasil penelitian menunjukkan bahwa GWS 39 D, GWS 110 D, GWS 18 Al, GWS 79 A, dan GWS 110 A2 diidentifikasi sebagai galur dengan hasil tinggi. GWS 74 D, GWS 39 B, GWS 79 A, GWS 73 D, GWS 18 Al, GWS 134 A1, dan GWS 110 Al diidentifikasi sebagai galur dengan tingkat ketahanan tinggi untuk ketahanan terhadap penyakit bercak daun. Dua dari enam belas baris memiliki hasil yang tinggi dan tingkat ketahanan tinggi untuk bercak daun, yaitu GWS 79 A dan GWS 18 Al.

Kata kunci : kacang tanah, uji daya hasil, ketahanan terhadap penyakit bercak daun

\section{PENDAHULUAN}

Kacang tanah (Arachis hypogaea L.) merupakan tanaman yang mempunyai arti ekonomi cukup penting karena berperan dalam memenuhi kebutuhan pangan dan pakan nasional. Kebutuhan kacang tanah dari tahun ke tahun meningkat sekitar $4,4 \%$ sedangkan produksi kacang tanah hanya meningkat sebesar 2,5\% (Widjanarko et al., 2009). Sehingga peningkatan produksi dan produktivitas kacang tanah perlu dilakukan sebagai upaya untuk

\footnotetext{
* Penulis untuk korespondensi. e-mail: yudiwanti@ipb.ac.id
}

memenuhi kebutuhan tersebut. Akan tetapi, saat ini terdapat banyak permasalahan yang menjadi penghambat dalam upaya untuk meningkatkan produksi dan produktivitas kacang tanah nasional, salah satu penyebabnya adalah gangguan penyakit.

Penyakit bercak daun yang disebabkan oleh dua macam jamur, yaitu Cercosporidium personatum (Berk. \& Curt.) Deighton dan Cercospora arachidicola ini merupakan penyakit yang dominan pada pertanaman kacang tanah di Indonesia. Menurut Semangun (2004) penyakit bercak daun dapat mengurangi produksi tanaman hingga $50 \%$. 
Salah satu upaya yang dapat dilakukan untuk mengatasi gangguan penyakit bercak daun adalah melalui teknik pemuliaan tanaman. Pemuliaan tanaman ini ditujukan untuk merakit varietas baru kacang tanah yang tahan penyakit bercak daun dan berdaya hasil tinggi.

Galur-galur kacang tanah yang diuji dalam penelitian ini merupakan galur generasi lanjut hasil persilangan antara kultivar Gajah dan galur introduksi GPNC-WS 4. Informasi yang diharapkan didapat dari penelitian ini yaitu diketahuinya galur-galur generasi lanjut hasil persilangan tersebut yang mendukung ketahanan terhadap penyakit bercak daun sekaligus berdaya hasil tinggi.

Galur yang terbukti tahan terhadap penyakit bercak daun dan berdaya hasil tinggi dapat diproses lebih lanjut untuk diajukan dan dilepas sebagai varietas baru kacang tanah yang unggul. Melalui penggunaan varietas unggul ini dan didukung oleh sistem budi daya tanaman yang baik, diharapkan dapat menjadi pendorong dalam upaya untuk meningkatkan produksi dan produktivitas kacang tanah. Penelitian ini bertujuan untuk mengevaluasi daya hasil 16 galur kacang tanah (Arachis hypogaea L.) tahan penyakit bercak daun hasil pemuliaan Departemen Agronomi dan Hortikultura, Fakultas Pertanian IPB.

\section{BAHAN DAN METODE}

Penelitian dilaksanakan di Kecamatan Ciranjang, Kabupaten Cianjur yang dimulai dari bulan Februari 2011 sampai bulan Mei 2011. Lokasi lahan penelitian terletak pada ketinggian 223 meter diatas permukaan laut. Selain itu, penelitian juga dilaksanakan di laboratorium Analisis Tanaman dan Kromatografi Institut Pertanian Bogor, untuk melakukan pengujian dan pengukuran kadar klorofil daun.

Bahan tanam yang digunakan adalah 20 genotipe kacang tanah yang terdiri atas 16 galur generasi lanjut GWS sebagai galur yang diuji, dan empat varietas komersial sebagai varietas pembandingnya. Galurgalur GWS yang diuji merupakan hasil persilangan antara varietas Gajah dan galur introduksi GPNC-WS 4 yang diperoleh dari koleksi Laboratorium Genetika dan Pemuliaan Tanaman, Departemen Agronomi dan Hortikultura, Fakultas Pertanian IPB. Varietas pembanding yaitu Gajah, Jerapah, Zebra Putih, dan Sima. Bahan lain yang digunakan yaitu pupuk anorganik (Urea, SP-36, KCL), pupuk kandang dari kotoran sapi, kapur dolomit, dan furadan. Peralatan yang digunakan adalah peralatan yang lazim digunakan dalam budidaya kacang tanah. Spektrofometer UV1800 digunakan untuk menentukan kadar klorofil pada daun.

Rancangan percobaan yang digunakan adalah Rancangan Kelompok Lengkap Teracak satu faktor yaitu genotipe (20 genotipe) dengan tiga ulangan. Jumlah petak percobaan yaitu 60 petak. Pengolahan data dilakukan dengan uji $\mathrm{F}$, perlakuan yang berpengaruh nyata diuji dengan uji lanjut t-Dunnett pada taraf nyata 5\% dan uji Kontras Ortogonal untuk karakter-karakter yang menjadi kriteria seleksi daya hasil dan ketahanan terhadap bercak daun.

Dua minggu sebelum penanaman, terlebih dahulu dilakukan pengolahan lahan dengan menggemburkan tanah, kemudian dibuat petak percobaan sebanyak 60 petak yang berukuran $4 \mathrm{~m} \mathrm{x}$ $3 \mathrm{~m}$ setiap petak. Pupuk kandang yang telah masak dan kapur dolomit diberikan satu minggu sebelum penanaman dengan dosis berturut-turut sebanyak 2 ton/ha dan $500 \mathrm{~kg} / \mathrm{ha}$.

Penanaman dilakukan dengan menggunakan jarak tanam $40 \mathrm{~cm}$ x $15 \mathrm{~cm}$ dan ditanam satu benih per lubang tanam. Pupuk anorganik diaplikasikan satu kali pada saat penanaman. Dosis pupuk yang digunakan yaitu $75 \mathrm{~kg}$ Urea/ha, $150 \mathrm{~kg}$ SP-36/ha, dan $50 \mathrm{~kg}$ $\mathrm{KCL} /$ ha yang diberikan dengan cara dialur di samping lubang tanam. Selain itu, furadan juga diberikan saat penanaman dengan dosis $12 \mathrm{~kg} / \mathrm{ha}$.

Pemeliharaan tanaman yang dilakukan meliputi penyulaman, penyiangan, pembumbunan, dan pengairan. Sistem pengairan dilakukan melalui pengairan tadah hujan. Penyulaman dilakukan pada 1 MST (Minggu Setelah Tanam). Penyiangan dilakukan setiap minggu sampai tanaman berumur 5 MST dan pembumbunan dilakukan saat 5 MST.

Pemanenan dilakukan saat tanaman berumur 100 hari. Pengeringan polong dan brangkasan tanaman dilakukan dengan cara dijemur \pm 8 jam setiap hari saat cuaca cerah selama 3 hari.

Pengamatan untuk hasil dilakukan dengan menggunakan ubinan $1 \mathrm{~m} \times 1 \mathrm{~m}$ pada masing-masing petak percobaan. Pengamatan untuk karakter lainnya dilakukan pada 10 tanaman contoh yang diambil secara acak dari tanaman di setiap ubinan. Peubah yang diamati mencakup: (1) tinggi tanaman saat panen, (2) jumlah cabang yang tumbuh pada tiap tanaman saat panen, (3) persentase panjang batang utama berdaun hijau, dihitung dengan persamaan : (panjang batang utama berdaun hijau/tinggi tanaman)x 100\%, (4) kadar klorofil daun, (5) indeks panen kering, dihitung dengan rumus : bobot polong bernas / bobot brangkasan, (6) jumlah polong total, polong bernas, dan polong cipo, (7) bobot polong total, polong bernas, dan polong cipo, (8) bobot biji per tanaman, dan bobot 100 butir biji.

Terhadap data yang diperoleh dilakukan 
analisis ragam dan dilanjutkan dengan uji nilai tengah tiap galur generasi lanjut GWS dengan varietas Gajah dan varietas pembanding terbaik tiap karakter yang berbeda nyata menggunakan uji t-Dunnett. Uji kontras ortogonal digunakan untuk karakterkarakter yang menjadi kriteria seleksi daya hasil dan ketahanan terhadap bercak daun. Selanjutnya dilakukan pendugaan ragam lingkungan $\left(\sigma^{2} e\right)$, ragam genetik $\left(\sigma^{2} g\right)$, dan ragam fenotipik $\left(\sigma^{2} p\right)$ berdasarkan komponen ragam, heritabilitas dalam arti luas $\left(\mathrm{h}^{2}{ }_{\mathrm{bs}}\right)$, koefisien keragaman genetik (KKG0, serta korelasi antar karakter.

\section{HASIL DAN PEMBAHASAN}

\section{Keragaan Umum Karakter Genotipe yang Diuji}

Keragaan umum untuk karakter-karakter yang diamati pada 20 genotipe kacang tanah disajikan pada Tabel 1. Nilai maksimum menunjukkan nilai tengah tertinggi suatu genotipe diantara genotipe lainnya untuk karakter-karakter tertentu yang diamati, begitu pula sebaliknya dengan nilai minimum yang menunjukkan nilai tengah terendah suatu genotipe diantara genotipe lainnya untuk karakter-karakter tertentu yang diamati.

Sima yang merupakan salah satu varietas pembanding dan digunakan sebagai pembanding untuk genotipe yang tahan penyakit bercak daun memiliki nilai tertinggi diantara genotipe lainnya untuk karakter tinggi tanaman, panjang batang utama berdaun hijau, dan persentase panjang batang utama berdaun hijau dengan nilai tengah atau rata-rata berturut-turut sebesar $53.5 \mathrm{~cm}, 42.5 \mathrm{~cm}$, dan $79.5 \%$. Karakter jumlah cabang (8.8) dan bobot biji per tanaman (19.0 gram) dengan nilai tertinggi terdapat pada galur GWS 79 A.

Di samping itu, Tabel 1 juga menunjukkan bahwa galur GWS 39 D memiliki nilai tengah atau rata-rata yang tertinggi untuk beberapa karakter yaitu jumlah polong total (26.8), jumlah polong bernas (25.5), bobot polong total (29.1 gram), dan bobot polong bernas (28.7 gram). Nilai tengah tertinggi untuk kadar klorofil $\left(7.3 \mu \mathrm{mol} / 100 \mathrm{~cm}^{2}\right)$, bobot 100 butir biji (56.5 gram), dan bobot brangkasan (36.9 gram) dimiliki oleh GWS $73 \mathrm{D}$, sedangkan indeks panen kering (1.2) terdapat pada GWS 72 A. Jumlah polong cipo dan bobot polong cipo tertinggi ditunjukkan oleh GWS 138 A dengan nilai tengah berturut-turut sebesar 2.3 dan 1.6 gram.

Hasil analisis ragam menunjukkan bahwa terdapat perbedaan yang nyata pada taraf $1 \%$ untuk karakter tinggi tanaman, jumlah cabang, panjang batang utama berdaun hijau, persentase panjang batang utama berdaun hijau, kadar klorofil, jumlah polong total, jumlah polong bernas, bobot 100 butir biji, dan bobot brangkasan. Karakter yang berbeda nyata pada taraf $5 \%$ terdapat pada indeks panen kering, sedangkan untuk karakter yang lainnya tidak berbeda nyata, yaitu jumlah polong cipo, bobot polong total, bobot polong bernas, bobot polong cipo, dan bobot biji per tanaman.

Tabel 1. Nilai Maksimum dan nilai minimum karakter pada 20 genotipe kacang tanah

\begin{tabular}{|c|c|c|}
\hline Karakter & $\begin{array}{c}\text { Nilai Maksimum } \\
\text { (Genotipe) }\end{array}$ & $\begin{array}{c}\text { Nilai Minimum } \\
\text { (Genotipe) }\end{array}$ \\
\hline $\begin{array}{l}\text { Tinggi tanaman } \\
(\mathrm{cm})\end{array}$ & $\begin{array}{c}53.5 \\
(\text { Sima })\end{array}$ & $\begin{array}{c}27.6 \\
\text { (GWS 134 A1) }\end{array}$ \\
\hline Jumlah cabang & $\begin{array}{c}8.8 \\
(\text { GWS } 79 \mathrm{~A})\end{array}$ & $\begin{array}{l}5 \\
\text { (Zebra Putih) }\end{array}$ \\
\hline $\begin{array}{l}\text { Panjang batang } \\
\text { utama berdaun } \\
\text { hijau }(\mathrm{cm})\end{array}$ & $\begin{array}{c}42.5 \\
(\text { Sima })\end{array}$ & $\begin{array}{c}5.9 \\
\text { (Gajah) }\end{array}$ \\
\hline $\begin{array}{l}\text { Persentase panjang } \\
\text { batang utama } \\
\text { berdaun hijau (\%) }\end{array}$ & $\begin{array}{c}79.5 \\
(\mathrm{Sima})\end{array}$ & $\begin{array}{c}18.8 \\
(\text { Gajah })\end{array}$ \\
\hline $\begin{array}{l}\text { Kadar klorofil } \\
(\mu \mathrm{mol} / 100 \mathrm{~cm} 2)\end{array}$ & $\begin{array}{c}7.3 \\
\text { (GWS } 73 \mathrm{D})\end{array}$ & $\begin{array}{c}4.5 \\
(\text { GWS } 72 \mathrm{~A})\end{array}$ \\
\hline $\begin{array}{l}\text { Jumlah polong total } \\
\text { (polong) }\end{array}$ & $\begin{array}{c}26.8 \\
\text { (GWS 39 D) }\end{array}$ & $\begin{array}{c}12.7 \\
(\mathrm{Sima})\end{array}$ \\
\hline $\begin{array}{l}\text { Jumlah polong } \\
\text { bernas (polong) }\end{array}$ & $\begin{array}{c}25.5 \\
\text { (GWS 39 D) }\end{array}$ & $\begin{array}{c}11.8 \\
(\mathrm{Gajah})\end{array}$ \\
\hline $\begin{array}{l}\text { Jumlah polong cipo } \\
\text { (polong) }\end{array}$ & $\begin{array}{c}2.3 \\
(\text { GWS } 138 \mathrm{~A})\end{array}$ & $\begin{array}{c}0.6 \\
(\mathrm{GWS} 74 \mathrm{~A} 1)\end{array}$ \\
\hline $\begin{array}{l}\text { Bobot polong total } \\
\text { (gram) }\end{array}$ & $\begin{array}{c}29.1 \\
(\text { GWS } 39 \mathrm{D})\end{array}$ & $\begin{array}{c}14.7 \\
(\text { Gajah })\end{array}$ \\
\hline $\begin{array}{l}\text { Bobot polong } \\
\text { bernas (gram) }\end{array}$ & $\begin{array}{c}28.7 \\
\text { (GWS } 39 \mathrm{D})\end{array}$ & $($ Gajah) \\
\hline $\begin{array}{l}\text { Bobot polong cipo } \\
\text { (gram) }\end{array}$ & $\begin{array}{c}1.6 \\
(\text { GWS 138 A) }\end{array}$ & $\begin{array}{c}0.3 \\
\text { (GWS 74 A1; } \\
\text { GWS 134 A1; } \\
\text { GWS 110 A1; } \\
\text { GWS 74 D; GWS } \\
\text { 110 D; Jerapah) }\end{array}$ \\
\hline $\begin{array}{l}\text { Bobot biji per } \\
\text { tanaman (gram) }\end{array}$ & $\begin{array}{c}19 \\
(\text { GWS } 79 A)\end{array}$ & $\begin{array}{c}9.5 \\
\text { (Gajah) }\end{array}$ \\
\hline $\begin{array}{l}\text { Bobot } 100 \text { butir biji } \\
\text { (gram) }\end{array}$ & $\begin{array}{c}56.5 \\
\text { (GWS } 73 \mathrm{D})\end{array}$ & $\begin{array}{c}42.5 \\
\text { (GWS } 110 \mathrm{D})\end{array}$ \\
\hline $\begin{array}{l}\text { Bobot brangkasan } \\
\text { (gram) }\end{array}$ & $\begin{array}{c}36.9 \\
\text { (GWS } 73 \text { D) }\end{array}$ & $\begin{array}{c}16.1 \\
(\text { Gajah })\end{array}$ \\
\hline $\begin{array}{l}\text { Indeks panen } \\
\text { kering }\end{array}$ & $\begin{array}{c}1.2 \\
(\mathrm{GWS} 72 \mathrm{~A})\end{array}$ & $\begin{array}{c}0.7 \\
\text { (GWS } 74 \mathrm{~A} 1 ; \\
\text { GWS 73 D; Sima) }\end{array}$ \\
\hline
\end{tabular}


Varietas pembanding yang digunakan dalam uji t-Dunnet adalah varietas Gajah dan varietas pembanding yang terbaik untuk setiap karakter pengamatan. Jerapah memiliki jumlah polong total, jumlah polong bernas, jumlah cabang, dan bobot 100 butir biji yang paling tinggi diantara varietas pembanding lainnya, sehingga Jerapah digunakan sebagai pembanding terbaik untuk karakter-karakter tersebut. Sima memiliki tinggi tanaman, persentase panjang batang utama berdaun hijau, kadar klorofil, dan bobot brangkasan yang paling tinggi, sehingga Sima digunakan sebagai pembanding terbaik untuk karakter-karakter tersebut, sedangkan nilai tertinggi untuk indeks panen kering dimiliki oleh Gajah. Seluruh karakter pengamatan tersebut juga dibandingkan dengan Gajah sebagai varietas pembanding untuk genotipe yang rentan penyakit bercak daun (Tabel 2).

Hasil uji lanjut untuk karakter yang berbeda nyata dengan menggunakan uji t-Dunnett yang disajikan pada Tabel 2, terlihat bahwa hanya GWS 39 D memiliki rata-rata jumlah polong total dan jumlah polong bernas yang nyata lebih tinggi dibandingkan dengan varietas Jerapah, sedangkan galur lainnya tidak berbeda nyata. Di lain pihak jika dibandingkan dengan Gajah, maka beberapa galur GWS memiliki jumlah polong total dan jumlah polong bernas yang nyata lebih tinggi dari Gajah, yaitu GWS 110 A2, GWS 79 A, GWS 18 A1, GWS 110 D, dan GWS 39 D.

Menurut Yudiwanti dan Ghani (2002) perbedaan jumlah polong ini dipengaruhi oleh jumlah cabang produktif dan persentase bunga yang membentuk polong. Selain itu, dilanjutkan kembali oleh Yudiwanti dan Ghani (2002) bahwa pembentukan polong dipengaruhi juga oleh ketersediaan hara dalam tanah, terutama kandungan unsur $\mathrm{P}, \mathrm{K}$, dan $\mathrm{Ca}$

Perbandingan nilai tengah atau rata-rata

Tabel 2. Nilai Tengah Beberapa Karakter Pengamatan yang Berbeda Nyata Berdasarkan Analisis Ragam pada 20 Genotipe Kacang Tanah

\begin{tabular}{|c|c|c|c|c|c|c|c|c|c|}
\hline Genotipe & $\begin{array}{l}\text { Jumlah } \\
\text { polong } \\
\text { total }\end{array}$ & $\begin{array}{l}\text { Jumlah } \\
\text { Polong } \\
\text { Bernas } \\
\text { (polong) }\end{array}$ & $\begin{array}{l}\text { Tinggi } \\
\text { Tanaman } \\
(\mathrm{cm})\end{array}$ & $\begin{array}{l}\text { Jumlah } \\
\text { Cabang }\end{array}$ & $\begin{array}{c}\text { Panjang } \\
\text { Batang } \\
\text { Utama } \\
\text { Berdaun } \\
\text { Hijau (\%) }\end{array}$ & $\begin{array}{c}\text { Kadar } \\
\text { Klorofil } \\
(\mu \mathrm{mol} / 100 \\
\mathrm{cm} 2)\end{array}$ & $\begin{array}{c}\text { Bobot } \\
100 \text { Butir } \\
\text { Biji } \\
\text { (gram) }\end{array}$ & $\begin{array}{c}\text { Bobot } \\
\text { Brangkasan } \\
(\text { gram })\end{array}$ & $\begin{array}{l}\text { Indeks } \\
\text { Panen } \\
\text { Kering }\end{array}$ \\
\hline GWS $39 \mathrm{~B}$ & 21.1 & 19.6 & $29.0 \mathrm{~h}$ & $4.0 \mathrm{a}$ & $49.8 \mathrm{ah}$ & 5.97 & 50.8 & 27.3 & 0.9 \\
\hline GWS 110 A2 & $23.1 \mathrm{a}$ & $21.6 \mathrm{a}$ & $30.0 \mathrm{~h}$ & 7.8 & $32.7 \mathrm{~h}$ & 4.98 & 46.3 & 25.9 & 0.9 \\
\hline GWS 134 D & 19.3 & 17.8 & $35.0 \mathrm{~h}$ & 7 & $36.4 \mathrm{~h}$ & 5.92 & 46.5 & 26.4 & 0.8 \\
\hline GWS 138 A & 18.8 & 16.5 & $33.9 \mathrm{~h}$ & 6.4 & $35.5 \mathrm{~h}$ & 5.52 & 56.3 & 26.4 & 0.9 \\
\hline GWS 74 A1 & 15.3 & 14.7 & $35.0 \mathrm{~h}$ & 6.4 & $35.3 \mathrm{~h}$ & 5.15 & 52.5 & 26.9 & 0.7 \\
\hline GWS $134 \mathrm{~A}$ & 19 & 18 & $33.7 \mathrm{~h}$ & 7.4 & $34.6 \mathrm{~h}$ & 5.11 & 49.3 & 22.9 & 1.0 \\
\hline GWS $27 \mathrm{C}$ & 21 & 19.8 & $38.5 \mathrm{~h}$ & $7.7 \mathrm{a}$ & $35.2 \mathrm{~h}$ & 6.39 & 49 & $32.2 \mathrm{a}$ & 0.8 \\
\hline GWS 79 A & $23.6 \mathrm{a}$ & $22.0 \mathrm{a}$ & $32.6 \mathrm{~h}$ & $8.8 \mathrm{ab}$ & $39.5 \mathrm{ah}$ & 5.1 & 53.7 & $34.0 \mathrm{a}$ & 0.9 \\
\hline GWS 73 D & 22 & 20 & 43.4 & 6.9 & $43.5 \mathrm{ah}$ & $7.25 \mathrm{a}$ & 56.5 & $36.9 \mathrm{a}$ & 0.7 \\
\hline GWS 18 A1 & $22.5 \mathrm{a}$ & $21.1 \mathrm{a}$ & $31.6 \mathrm{~h}$ & 7 & $38.2 \mathrm{ah}$ & 6.34 & $43.3 \mathrm{f}$ & 27.1 & 0.8 \\
\hline GWS 134 A1 & 17.2 & 16.4 & $27.6 \mathrm{~h}$ & 7.2 & $42.9 \mathrm{ah}$ & 5.24 & 52 & 23.1 & 0.9 \\
\hline GWS 110 A1 & 22.3 & 21.4 & $29.5 \mathrm{~h}$ & $7.5 \mathrm{a}$ & $41.1 \mathrm{ah}$ & 5.12 & 50 & 23 & 1.0 \\
\hline GWS 74 D & 18.3 & 17.3 & $37.1 \mathrm{~h}$ & 6.5 & $50.4 \mathrm{ah}$ & 4.99 & 52.3 & $29.3 \mathrm{a}$ & 0.8 \\
\hline GWS 110 D & $22.8 \mathrm{a}$ & $21.7 \mathrm{a}$ & $28.4 \mathrm{~h}$ & 7.1 & $34.0 \mathrm{~h}$ & 5.24 & $42.5 \mathrm{f}$ & 21.8 & 1.0 \\
\hline GWS $72 \mathrm{~A}$ & 21.3 & 20 & $30.6 \mathrm{~h}$ & $7.8 \mathrm{a}$ & $30.0 \mathrm{~h}$ & $4.35 \mathrm{~h}$ & 53.2 & 23.3 & 1.2 \\
\hline GWS $39 \mathrm{D}$ & $26.8 \mathrm{ab}$ & $25.5 \mathrm{ab}$ & $33.8 \mathrm{~h}$ & $7.7 \mathrm{a}$ & $30.1 \mathrm{~h}$ & 5.91 & 48.2 & $30.3 \mathrm{a}$ & 1.0 \\
\hline Gajah & 13 & 11.8 & 31.4 & 5.6 & 18.8 & 4.84 & 45.7 & 16.1 & 1.0 \\
\hline Zebra Putih & 14.5 & 13.2 & 30.2 & 5 & 77.3 & 7.04 & 44 & 22.7 & 0.9 \\
\hline Jerapah & 15.5 & 14.7 & 30.5 & 6.7 & 32.9 & 6.27 & 55.5 & 24.6 & 0.9 \\
\hline Sima & 12.7 & 11.9 & 53.5 & 5.1 & 79.5 & 7.22 & 45.8 & 32.6 & 0.7 \\
\hline
\end{tabular}

Keterangan : Indeks huruf pada kolom yang sama diolah lanjut dari hasil uji t-Dunnett pada taraf 5\%, menunjukan bahwa : a : nyata $>$ Gajah, b : nyata $>$ Jerapah, c : nyata $>$ Zebra Putih, d : nyata $>$ Sima, e : nyata $<$ Gajah, f: nyata $<$ Jerapah, g : nyata $<$ Zebra Putih, h : nyata $<$ Sima 
tinggi tanaman dari semua galur GWS dengan Gajah menunjukan nilai yang tidak berbeda nyata berdasarkan uji t-Dunnett. Bila dibandingkan dengan Sima, galurgalur GWS yang diuji memiliki tinggi tanaman nyata lebih rendah dari Sima, kecuali GWS 73 D yang tidak berbeda nyata dengan Sima.

Ukuran tanaman yang terlalu tinggi ternyata dapat memberikan pengaruh negatif terhadap kondisi tanaman tersebut di lahan tanam. Berdasarkan pengamatan visual di lapangan, tanaman kacang tanah dengan ukuran yang relatif lebih tinggi seperti Sima, lebih mudah rebah saat terkena angin yang cukup besar dibandingkan dengan tanaman yang ukurannya lebih rendah. Hal yang sama juga diungkapkan oleh Riduan dan Sudarsono (2005) dalam penelitiannya yang menyatakan bahwa tanaman yang tinggi dapat meningkatkan kerebahan tanaman kacang tanah di lapangan, sehingga kerebahan tanaman ini dapat berakibat pada tingginya kelembaban di bawah kanopi tanaman yang mendukung perkembangan penyakit.

Persentase panjang batang utama berdaun hijau untuk semua galur GWS yang diuji juga memiliki nilai yang nyata lebih rendah dibandingkan dengan Sima. Akan tetapi, jika galur GWS ini dibandingkan dengan Gajah, maka terdapat beberapa galur GWS yang memiliki nilai nyata lebih tinggi dibandingkan dengan Gajah, yaitu GWS 39 B, GWS 79 A, GWS 73 D, GWS 18 A1, GWS 134 A1, GWS 110 A1, dan GWS 74 D.

Diantara galur GWS yang diuji berdasarkan uji t-Dunnett, GWS 72 A menjadi satu-satunya galur GWS yang memiliki kadar klorofil yang nyata lebih rendah dibandingkan dengan Sima, sedangkan galur GWS lainnya memiliki nilai yang tidak berbeda nyata. Di sisi lain bila galur GWS dibandingkan dengan Gajah, maka hanya GWS 73 D yang nyata lebih tinggi dari Gajah dan galur GWS lainnya tidak berbeda nyata.

Karakter jumlah cabang pada Tabel 2 memperlihatkan bahwa hanya terdapat satu galur GWS yang memiliki jumlah cabang yang nyata lebih tinggi dari varietas Jerapah sebagai pembanding terbaik, yaitu GWS 79 A dan untuk galur GWS lainnya tidak berbeda nyata dari Jerapah. Terdapat galur GWS yang memiliki jumlah cabang nyata lebih tinggi dari Gajah, yaitu GWS 39 B, GWS 110 A2, GWS 134 A, GWS 27 C, GWS 79 A, GWS 110 A1, GWS 72 A, dan GWS $39 \mathrm{D}$.

Menurut Riduan dan Sudarsono (2005) peningkatanjumlahcabangbiasanyaberasosiasi dengan peningkatan daya hasil yang menghasilkan polong dan biji lebih banyak. Akan tetapi, ditambahkan oleh Yudiwanti dan Ghani (2002) bahwa pengaruh jumlah cabang terhadap daya hasil ini akan lebih ditentukan oleh jumlah cabang produktif dan persentase bunga yang membentuk polong.

Berdasarkan hasil uji t-Dunnett, GWS 18 A1 dan GWS 110 D merupakan galur GWS dengan bobot 100 biji yang nyata lebih rendah dari Jerapah, sedangkan galur GWS lainnya tidak berbeda nyata. Seluruh galur GWS yang dibandingkan dengan Gajah, memiliki bobot 100 butir biji yang tidak berbeda nyata berdasarkan uji t-Dunnett.

Karakter bobot brangkasan (Tabel 2) terlihat tidak ada perbedaan nyata antara seluruh galur GWS dengan Sima. Bila dibandingkan dengan Gajah, terdapat beberapa galur GWS yang memiliki bobot brangkasan yang nyata lebih tinggi dari Gajah, yaitu GWS 27 C, GWS 79 A, GWS 73 D, GWS 74 D, dan GWS 39 D.

Berdasarkan pengamatan di lapangan, bobot brangkasan tanaman diduga dipengaruhi oleh ketahanannya terhadap penyakit bercak daun. Hal ini karena semakin tidak tahan suatu genotipe terhadap penyakit bercak daun, akan semakin banyak daun yang kering dan akhirnya gugur. Banyaknya daun yang gugur ini dapat mengurangi bobot brangkasan tanaman. Selain itu, bobot brangkasan diduga dipengaruhi oleh jumlah cabang yang terbentuk. Semakin banyak jumlah cabang yang terbentuk maka akan berpotensi untuk meningkatkan bobot brangkasannya. Selain itu, hasil yang ditunjukkan pada Tabel 2 terlihat bahwa tidak ada perbedaan nyata untuk nilai indeks panen kering seluruh galur GWS dengan Gajah berdasarkan uji t-Dunnett.

\section{Pendugaan Parameter Genetik}

Heritabilitas menspesifikasikan proporsi variabilitas total yang disebabkan oleh faktor genetik, atau perbandingan ragam genetik terhadap ragam total (Allard, 1992). Nilai heritabilitas sangat menentukan efisiensi seleksi karena menggambarkan proporsi ragam genetik yang diwariskan oleh tetua kepada zuriatnya. Nilai heritabilitas digolongkan rendah bila $\mathrm{h}^{2}<0.2$, heritabilitas sedang bila $0.2 \leq \mathrm{h}^{2} \leq 0.5$, dan heritabilitas tinggi bila $\mathrm{h}^{2}>0.5$ (Stansfield, 1983).

Karakter-karakter yang memiliki nilai heritabilitas tinggi yaitu tinggi tanaman, jumlah cabang, persentase panjang batang utama berdaun hijau, kadar klorofil, jumlah polong total, jumlah polong bernas, bobot 100 butir biji, dan bobot brangkasan. Karakter yang memiliki nilai heritabilitas sedang yaitu bobot polong total, bobot polong bernas, bobot polong cipo, bobot biji per tanaman, dan indeks panen kering. Sedangkan karakter dengan nilai heritabilitas rendah terdapat pada jumlah polong cipo (Tabel 3).

Kelompok karakter dengan nilai heritabilitas 
Tabel 3. Parameter genetik beberapa karakter pengamatan pada 20 genotipe kacang tanah

\begin{tabular}{lcc}
\hline Karakter & $\mathrm{h}^{2} \mathrm{bs}$ & $\mathrm{KKG}(\%)$ \\
\hline Tinggi tanaman & 0.68 & 14.66 \\
Jumlah cabang & 0.83 & 12.22 \\
Persentase panjang & 0.92 & 34.25 \\
batang utama berdaun & & \\
hijau & & \\
Kadar klorofil & 0.56 & 10.96 \\
Jumlah polong total & 0.68 & 16.15 \\
Jumlah polong bernas & 0.69 & 37.06 \\
Jumlah polong cipo & 0.00 & 0.00 \\
Bobot polong total & 0.42 & 9.11 \\
Bobot polong bernas & 0.42 & 9.24 \\
Bobot polong cipo & 0.25 & 10.89 \\
Bobot biji per tanaman & 0.28 & 7.15 \\
Bobot 100 butir biji & 0.62 & 6.84 \\
Bobot brangkasan & 0.72 & 15.51 \\
Indeks panen kering & 0.50 & 9.17 \\
\hline
\end{tabular}

Keterangan $: h^{2} b s=$ heritabilitas arti luas, $\mathrm{KKG}=$ Koefisien Keragaman Genetik

yang tinggi menunjukkan bahwa penampilan fenotipik kelompok karakter tersebut kurang dipengaruhi oleh lingkungan, sedangkan kelompok karakter dengan nilai heritabilitas sedang dan rendah karakter fenotipiknya lebih dipengaruhi oleh faktor lingkungan. Nilai heritabilitas nol seperti pada karakter jumlah polong cipo menunjukkan pengaruh lingkungan yang sangat besar terhadap karakter fenotipik tersebut.

Koefisien keragaman genetik (KKG) menunjukkan besaran ragam genetik dalam populasi. Semakin tinggi nilai KKG suatu karakter maka semakin besar peluang untuk dilakukan seleksi pada karakter tersebut. Murdaningsih et al. dalam Sutina (2003) menyebutkan bahwa kriteria nilai KKG dapat digolongkan menjadi lima kriteria yaitu sempit $(0<$ $\mathrm{x} \leq 10.94)$, agak sempit $(10.94<\mathrm{x} \leq 21.88)$, agak luas $(21.88<x \leq 32.83)$, luas $(32.88<x \leq 43.77)$, dan sangat luas $(43.77<\mathrm{x})$.

Berdasarkan persentase nilai KKG yang ditunjukkan pada Tabel 3, terlihat bahwa karakter jumlah polong cipo, bobot polong total, bobot polong bernas, bobot biji per tanaman, bobot 100 butir biji, bobot polong cipo, dan indeks panen kering memiliki nilai KKG yang sempit. Nilai KKG yang agak sempit dimiliki oleh karakter tinggi tanaman, jumlah cabang, kadar klorofil, jumlah polong total, dan bobot brangkasan. Sedangkan karakter persentase panjang batang utama berdaun hijau dan jumlah polong bernas memiliki nilai KKG yang besar.

\section{Korelasi Antar Karakter Pengamatan}

Daya hasil merupakan karakter kuantitatif yang sangat dipengaruhi oleh karakter komponen hasil maupun karakter agronomi lain yang terkait dengan daya hasil. Keeratan hubungan antara karakter daya hasil dengan karakter lain yang mempengaruhi daya hasil dapat diduga dengan menghitung nilai koefisien korelasi antara kedua karakter (Wirnas et al., 2005).

Hasil analisis korelasi menunjukkan bahwa terdapat enam dari 14 karakter pengamatan yang berkorelasi nyata dan positif dengan bobot biji per tanaman sebagai karakter daya hasil, yaitu jumlah cabang $(r=0.655)$, jumlah polong total $(r=0.759)$, jumlah polong bernas $(r=0.756)$, bobot polong total $(r$ $=0.961)$, bobot polong bernas $(\mathrm{r}=0.933)$, dan bobot brangkasan $(r=0.661)$. Sedangkan karakter lainnya yaitu tinggi tanaman, panjang batang utama berdaun hijau, persentase panjang batang utama berdaun hjau, kadar klorofil, jumlah polong cipo, bobot polong cipo, bobot 100 butir biji, dan indeks panen kering tidak berkorelasi nyata dengan hasil.

Nilai korelasi antara enam karakter yang berkorelasi nyata dengan daya hasil disajikan pada Tabel 4. Nilai korelasi yang nyata dan positif tersebut menunjukkan bahwa peningkatan nilai dari keenam komponen hasil tersebut maka akan meningkatkan daya hasil. Bobot polong total dan bobot polong bernas memiliki korelasi positif paling tinggi terhadap bobot biji per tanaman berturut-turut sebesar 0.961 dan 0.933 dibandingkan karakter lain, artinya kedua karakter ini memiliki hubungan yang erat dengan karakter bobot biji per tanaman.

\section{Seleksi Galur-Galur GWS Terbaik}

Sebelum dilakukan seleksi terhadap 16 galur GWS terbaik, terlebih dahulu dilakukan pemilihan kriteria seleksi pada karakter-karakter yang dapat mencerminkan potensi galur GWS tersebut dalam hal daya hasil dan ketahanannya terhadap penyakit bercak daun. Kriteria seleksi untuk ketahanan terhadap bercak daun digunakan karakter persentase panjang batang utama berdaun hijau, sedangkan untuk kriteria daya hasil digunakan karakter-karakter yang berkorelasi nyata dengan daya hasil dan memiliki nilai duga heritabilitas yang tinggi. Seleksi akan efektif dilakukan pada karakter-karakter yang memiliki nilai 
Bul. Agrohorti 1 (1) : 45 - 53 (2013)

Tabel 4. Koefisien korelasi antara enam karakter pengamatan dengan daya hasil

\begin{tabular}{lllllll}
\hline & JPT & JPB & BPT & BPB & BB & BBP \\
\hline JC & $0.820^{* *}$ & $0.833^{* *}$ & $0.562^{* *}$ & $0.530^{*}$ & 0.25 & $0.655^{* *}$ \\
& $<.0001$ & $<.0001$ & 0.010 & 0.016 & 0.288 & 0.003 \\
JPT & & $0.995^{* *}$ & $0.740^{* *}$ & $0.711^{* *}$ & 0.338 & $0.759^{* *}$ \\
& & $<.0001$ & 0.000 & 0.000 & 0.145 & 0.000 \\
JPB & & $0.725^{* *}$ & $0.709^{* *}$ & 0.317 & $0.756^{* *}$ \\
& & 0.000 & 0.001 & 0.174 & 0.000 \\
BPT & & & $0.964^{* *}$ & $0.739^{* *}$ & $0.961^{* *}$ \\
& & & $<.0001$ & 0.000 & $<.0001$ \\
BPB & & & & $0.731^{* *}$ & $0.933^{* *}$ \\
& & & & 0.000 & $<.0001$ \\
BB & & & & & & $0.661^{* *}$ \\
& & & & & & \\
\hline
\end{tabular}

Keterangan : 1. JC : Jumlah Cabang, JPT: Jumlah Polong Total, JPB: Jumlah Polong Bernas, BPT: Bobot Polong Total, BPB: Bobot Polong Bernas, BB: Bobot Brangkasan, BBP: Bobot Biji per Tanaman.

2. * : berbeda nyata pada taraf $5 \%, * *$ : berbeda nyata pada taraf $1 \%$.

duga heritabilitas yang tinggi, karena sifat tersebut akan diwariskan secara kuat kepada keturunannya.

Menurut hasil penelitian Yudiwanti et al. (2006) karakter persen panjang batang utama yang berdaun hijau prospektif diterapkan sebagai peubah tingkat ketahanan terhadap bercak daun secara visual di lapangan. Peubah ini juga memiliki nilai duga heritabilitas arti luas yang tinggi, yaitu mencapai $80.77 \%$ yang menunjukkan bahwa keragaman peubah tersebut lebih dipengaruhi oleh faktor genetik.

Berdasarkan pembahasan sebelumnya, karakter-karakter yang berkorelasi nyata dengan daya hasil dan memiliki nilai duga heritabilitas yang tinggi yaitu jumlah cabang $\left(\mathrm{r}=0.655 ; \mathrm{h}^{2}{ }_{\text {bs }}=0.83\right)$, jumlah polong total $\left(\mathrm{r}=0.759 ; \mathrm{h}^{2}{ }_{\mathrm{bs}}=0.68\right)$, jumlah polong bernas $\left(\mathrm{r}=0.756 ; \mathrm{h}^{2}{ }_{\mathrm{bs}}=0.69\right)$, dan bobot brangkasan $\left(\mathrm{r}=0.661 ; \mathrm{h}^{2}=0.72\right)$. Akan tetapi diantara karakterkarakter tersebut hanya karakter jumlah polong total yang digunakan sebagai kriteria seleksi.

Menurut Yudiwanti et al. (1998) penyakit bercak daun berkembang pada pertanaman setelah polong terbentuk. Oleh karena itu, pengaruh penyakit ini terhadap pengurangan hasil lebih diakibatkan oleh pengaruhnya terhadap pengurangan kemampuan tanaman dalam pengisian polong, bukan terhadap pengurangan jumlah polong. Di lain pihak, karena polong terbentuk sebelum penyakit berkembang pada tanaman, maka jumlahnya kurang dipengaruhi oleh serangan patogen. Oleh karena itu, karakter jumlah polong total lebih mencerminkan potensi genetik daya hasil genotipe kacang tanah berkaitan dengan penyakit bercak daun.

Galur-galur GWS terbaik dipilih berdasarkan pada galur yang memiliki persentase panjang batang utama berdaun hijau sekaligus memiliki jumlah polong total yang lebih tinggi diantara galur lainnya. Untuk mempersempit proses seleksi, maka dipilih galur-galur dengan persentase panjang batang utama berdaun hijau dan jumlah polong total yang nyata lebih tinggi

Tabel 5. Rekapitulasi Uji Kontras Ortogonal Jumlah Polong Total Beberapa Galur GWS Terpilih

\begin{tabular}{lcccc}
\hline $\begin{array}{l}\text { Kontras } \\
\text { (a vs b) }\end{array}$ & $\begin{array}{l}\text { Rataan a } \\
\text { (polong) }\end{array}$ & $\begin{array}{l}\text { Rataan b } \\
\text { (polong) }\end{array}$ & F-hitung & Pr>F \\
\hline $\begin{array}{l}\text { GWS39D vs } \\
\text { (GWS110D }\end{array}$ & 26.8 & 23 & $5.28^{*}$ & 0.027 \\
GWS18A1 & & & & \\
GWS79A & & & & \\
GWS110A2) & & & & \\
GWS79A vs & 23.6 & 22.8 & $6.12 *$ & 0.018 \\
(GWS18A1 & & & & \\
GWS110D & & & & \\
GWS110A2) & & & & \\
GWS110A2 & 22.8 & 22.8 & $5.99 *$ & 0.019 \\
vs & & & & \\
(GWS18A1 & & & & \\
GWS110D ) & & & & \\
GWS110D & 23.1 & 22.5 & 3.52 tn & 0.068 \\
vs GWS18A1 & & & & \\
\hline
\end{tabular}

Keterangan : tn : tidak berbeda nyata, $*$ : berbeda nyata pada taraf $5 \%, * *$ : berbeda nyata pada taraf $1 \%$ 
Tabel 6. Rekapitulasi Uji Kontras Ortogonal Persentase Panjang Batang Utama Berdaun Hijau Beberapa Galur GWS Terpilih

\begin{tabular}{|c|c|c|c|c|}
\hline $\begin{array}{l}\text { Kontras } \\
(\mathrm{a} \text { vs b) }\end{array}$ & $\begin{array}{c}\text { Rataan } \\
\text { a (\%) }\end{array}$ & $\begin{array}{c}\text { Rataan } \\
\text { b (\%) }\end{array}$ & $\begin{array}{c}\text { F- } \\
\text { hitung }\end{array}$ & $\operatorname{Pr}>\mathrm{F}$ \\
\hline $\begin{array}{l}\text { GWS74D vs } \\
\text { ( GWS39B } \\
\text { GWS79A } \\
\text { GWS73D } \\
\text { GWS18A1 } \\
\text { GWS134A1 } \\
\text { GWS110A1 ) }\end{array}$ & 50.4 & 42.5 & $23.66^{* *}$ & $<.0001$ \\
\hline $\begin{array}{l}\text { GWS39B vs } \\
\text { ( GWS79A } \\
\text { GWS73D } \\
\text { GWS18A1 } \\
\text { GWS134A1 } \\
\text { GWS110A1 ) }\end{array}$ & 49.8 & 41.04 & $6.32 *$ & 0.016 \\
\hline $\begin{array}{l}\text { GWS73D vs } \\
\text { ( GWS79A } \\
\text { GWS18A1 } \\
\text { GWS134A1 } \\
\text { GWS110A1 ) }\end{array}$ & 43.5 & 40.43 & $6.67 *$ & 0.014 \\
\hline $\begin{array}{l}\text { GWS134A1 } \\
\text { vs ( GWS79A } \\
\text { GWS18A1 } \\
\text { GWS110A1) }\end{array}$ & 42.9 & 39.60 & $3.74 \mathrm{tn}$ & 0.061 \\
\hline $\begin{array}{l}\text { GWS110A1 } \\
\text { vs ( GWS79A } \\
\text { GWS18A1) }\end{array}$ & 41.1 & 38.85 & $4.23 \mathrm{tn}$ & 0.047 \\
\hline $\begin{array}{l}\text { GWS79A vs } \\
\text { GWS18A1 }\end{array}$ & 39.5 & 38.20 & $11.21^{* *}$ & 0.002 \\
\hline
\end{tabular}

Keterangan : tn : tidak berbeda nyata, * : berbeda nyata pada taraf $5 \%, * *$ : berbeda nyata pada taraf $1 \%$

dari Gajah sebagai pembanding genotipe yang rentan terhadap bercak daun berdasarkan hasil uji lanjut tDunnett. Sebagai penunjang untuk melihat galur yang terbaik maka dilakukan uji kontras ortogonal diantara galur-galur terpilih tersebut.

Hasil uji kontras ortogonal pada Tabel 5 menunjukkan bahwa galur GWS 39 D memiliki jumlah polong total yang nyata lebih banyak diantara galurgalur terpilih lainnya dan dapat dijadikan sebagai galur dengan daya hasil terbaik. Hasil uji kontras ortogonal pada Tabel 6 menunjukkan bahwa galur galur GWS 74 D memiliki persentase panjang batang utama berdaun hijau yang nyata lebih tinggi dibandingkan dengan galur-galur terpilih lainnya dan galur GWS 74 D dapat dijadikan sebagai galur yang memiliki tingkat ketahanan terhadap bercak daun yang terbaik.
Terdapat galur-galur GWS terbaik yang memiliki jumlah polong total sebagai kriteria daya hasil yang lebih tinggi diantara galur lainnya. Galur GWS yang memiliki daya hasil terbaik yaitu GWS 39 D, GWS 110 D, GWS 18A 1, GWS 79 A, dan GWS 110 A2. Di samping itu, terdapat juga galur-galur GWS terbaik yang memiliki tingkat ketahanan yang lebih tinggi diantara galur lainnya, yaitu GWS 74 D, GWS 39 B, GWS 79 A, GWS 73 D, GWS 18 A1, GWS 134 A1, dan GWS 110 A1. Dari kelompok galur-galur terbaik tersebut terdapat dua galur GWS yang memiliki daya hasil tinggi sekaligus tahan terhadap penyakit bercak daun yaitu GWS 79 A dan GWS 18A 1.

\section{KESIMPULAN}

Terdapat kelompok galur terbaik yang berdaya hasil nyata lebih tinggi dari Gajah yaitu GWS 39 D, GWS 110 D, GWS 18A 1, GWS 79 A, dan GWS 110 A2. Terdapat juga kelompok galur yang nyata lebih tahan penyakit bercak daun dari Gajah yaitu GWS 74 D, GW S39 B, GWS 79 A, GWS 73 D, GWS 18 A1, GWS 134 A1, dan GWS 110 A1. Dua dari 16 galur GWS yang diuji memiliki daya hasil tinggi sekaligus tahan terhadap penyakit bercak daun yaitu GWS 79 A dan GWS 18 A1.

\section{DAFTAR PUSTAKA}

Allard, R.W. 1992. Pemuliaan Tanaman : Edisi Baru (diterjemahkan dari : Principles of Plant Breeding, penerjemah : Manna). Rineka Cipta. Jakarta. 336 hal.

Riduan, A., dan Sudarsono. 2005 Daya hasil sepuluh galur introgresi kacang tanah hasil silangan antara Arachis cardenasii dan A. hypogaea. Hayati 12(3):116-120.

Semangun, H. 2004. Penyakit-Penyakit Tanaman Pangan di Indonesia. Gadjah Mada University Press. Yogyakarta. 449 hal.

Stansfield, W.D. 1983. Theory and Problems of Genetics Second Edition. Mc-Graw-Hill Inc. United States of America. 392 hal.

Sutina, D. 2003. Pendugaan Heritabilitas Karakter Polong Berbiji Tiga pada Zuriat Hasil Persilangan Kacang Tanah (Arachis hypogaea L.) Varietas Gajah dan GP-NCWS4. Skripsi. Program Sarjana, Institut Pertanian Bogor. Bogor. 32 hal.

Widjanarko, A., A. Taufiq, dan A.A. Rahmianna. 2009. Pengaturan jarak tanam ubikayu dan kacang 
tanah untuk meningkatkan indeks pertanaman di lahan kering masam Banjarnegara. http://www.balitkabi.litbang.deptan.go.id. [1 September 2010].

Wirnas, D., Sobir, dan M. Surahman. 2005. Pengembangan kriteria seleksi pada Pisang (Musa sp.) berdasarkan analisis lintas. Bul. Agron. (33) 3:48-54.

Yudiwanti, B. Wirawan, D. Wirnas. 2006. Korelasi Antara Kandungan Klorofil, Ketahanan Terhadap Bercak Daun dan Daya Hasil pada Kacang Tanah. Prosiding Seminar Nasional Bioteknologi dan Pemuliaan Tanaman. Departemen Agronomi dan Hortikultura
Faperta IPB. Bogor. 316-319 hal.

Yudiwanti, dan M.A. Ghani. 2002. Keragaan Daya Hasil Galur-Galur Kacang Tanah Hasil Persilangan Varietas Gajah dengan Galur GPNC-WS4. Makalah Seminar Nasional Agronomi. Perhimpunan Agronomi Indonesia (PERAGI). Bogor.

Yudiwanti, S. Sastrosumarjo, S. Hadi, S. Karama, A. Sukarti, dan A.A. Mattjik. 1998. Korelasi genotipik antara hasil dengan tingkat ketahanan terhadap penyakit bercak daun hitam pada kacang tanah. Bul. Agron 26(1):16-21. 